\title{
ON THE EFFICACY OF TRANSLATION METHODS AND THE FUNCTIONAL CURRENCY APPROACH IN REPORTING PRICE LEVEL CHANGES
}

\author{
Jatinder P. Singh* \\ Department of Management Studies, Indian Institute of Technology Roorkee, Uttarakhand, India
}

This article provides an evaluation of translation accounting through a logical and deductive analysis of the concepts. The relationship between the inflation of constituent countries and the methods of translation is explored. It is established that only the Current Value (Purchasing Power Parity) (PPP) Method correctly reports the effects of the inflation of both countries. The Current Rate Method fails to correctly report the effect of the subsidiary country's inflation and the temporal method does not correctly report the parent country's inflation. The efficacy of FAS 52 (USA) and the functional currency concept is examined. Under FAS 52, the functional currency determines the method to be adopted for translation and hence the accounts of the subsidiary that are subject to an exchange rate risk. It is, however, argued that the exchange rate risk is related to violations of Purchasing Power Parity. The degree of such violations should, therefore, form the premise on which the functional currency and translation method should be selected.

Keywords: foreign currency exposure, translation exposure, current rate method, temporal method, purchasing power parity, FAS 52, functional currency

JEL Classification: M41

\section{INTRODUCTION}

A complete renaissance of trade and commerce is in progress across the world perpetrated by the information technology revolution. Trading in international markets is no longer a novelty, either - exports and imports are becoming commonplace with the eradication of trade boundaries and barriers.

\footnotetext{
*Correspondence to: J .P. Singh, Department of Management Studies ,Indian Institute of Technology Roorkee, 247667 Uttarakhand, India; e-mail: jpsiitr@gmail.com
}

Foreign exchange markets have similarly been upgraded with a considerable reduction in various frictional losses like transaction costs, delivery delays etc. With a gradual progression in the market efficiencies towards perfection, the intensity of competition has also escalated worldwide. Corporates are now adopting innovative strategies in an effort to maintain margins and manage subsistence. These include business processes engineering, on the one hand, and efficient organizational structuring, on the other. For instance, setting up foreign corporate subsidiaries to manage overseas operations has 
become very popular. Corporate laws of most countries require the consolidation of the accounts of overseas subsidiaries with those of the parent company which, in turn, necessitates the conversion of the subsidiary accounts from the currency in which they are maintained by the subsidiary to the reporting currency of the parent company. It is here that the roles of translation accounting and the concept of the functional "currency" come into play. The objective of this paper is to examine and analyze various approaches to translation accounting highlighting their implications in describing the economic reality. Accordingly, we set up the following null hypotheses $\mathrm{H}_{0}^{\mathrm{i}}$ and the corresponding alternative hypotheses $\mathrm{H}_{1}^{\mathrm{i}}$ for testing:

$\mathrm{H}_{0}^{(\mathrm{P}) \mathrm{CV} / \mathrm{CR} / \mathrm{TEMP}}$ : The CV ( Current Value) / CR (Current Rate) / Temp (Temporal) method correctly reports the parent company's home country inflation;

$\mathrm{H}_{0}^{(\mathrm{S}) \mathrm{CV} / \mathrm{CR} / \mathrm{TEMP}}$ : The CV ( Current Value) / CR (Current Rate) / Temp (Temporal) method correctly reports the subsidiary company's home country inflation;

with the usual corresponding alternative hypotheses $\mathrm{H}_{1}^{(\mathrm{P}) \mathrm{CV} / \mathrm{CR} / \mathrm{TEMP}}$ and $\mathrm{H}_{1}^{(\mathrm{S}) \mathrm{CV} / \mathrm{CR} / \mathrm{TEMP}}$. In addition to the above, we examine the efficacy of the FAS 52 provisions and the related "functional currency" concept in correctly reporting the effect of price level changes in the two countries i.e. we put to test the following null hypothesis:

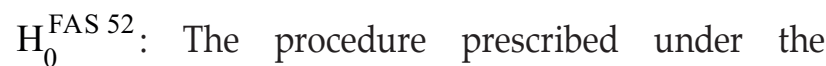
provisions of FAS 52 for the translation of the foreign subsidiary's accounts correctly reports the effects of the price level changes in the two constituent countries

with the corresponding alternative hypothesis $\mathrm{H}_{1}^{\mathrm{FAS}} 52$. We shall put these hypotheses to examination on the basis of logical reasoning and a deductive analysis of the relevant concepts and theoretical foundations.

The Financial Accounting Standard No 52 (FAS 52) promulgated by the Financial Accounting Standards Board (FASB) of the United States introduced the concept of a "functional currency" into the statute book for the first time. Para 5 of the said standard defines a "functional currency" in relation to a subsidiary as "the currency of the primary economic environment in which the entity operates; normally, that is the currency of the environment in which an entity primarily generates and expends cash". Under FAS 52, it shall be the functional currency, designated as above, that shall determine the method to be adopted for the translation of the accounts of the subsidiary as well as the mode of the disposition of the resulting translation gains/losses. Although the designation/identification of the functional currency is left to the discretion of the management, FAS 52 does, in Appendix A thereto, elucidate the criteria to be considered for such designation. In essence, the prescribed criteria targets at determining the extent of independence in the operations of the subsidiary - if the subsidiary enjoys significant independence in its operations and decision making, FAS 52 recommends the subsidiary's local currency to be the "functional currency". In other cases, it would usually be the US Dollar. Nevertheless, in a few cases, a foreign subsidiary's functional currency may be a foreign currency other than the local currency of the subsidiary or the US Dollar.

The following explicit considerations should go into the identification of a "functional currency" as per the guidance afforded by FAS 52 (Evans \& Doupnik, 1986; Hosseini \& Zabihollah, 1988):

- (i) the extent to which the parent's cash flows are affected by cash flows related to the foreign entity's individual assets and liabilities, and (ii) the extent to which these cash flows are in the foreign currency;

- the extent to which sales prices of the foreign entity's products respond in the short term to changes in the exchange rate;

- the existence of an active local market for the foreign entity's product;

- the extent to which labor, materials and other costs for the foreign entity's products are incurred locally or elsewhere; 
- (i) the denomination of a debt of the foreign entity and (ii) the extent to which funds generated by the foreign entity's operations are sufficient to service the existing and projected debt obligations; and

- (i) the quantum of intercompany transactions and (ii) the extent of intercompany interrelationships between the operations of the foreign entity and the parent company.

Of these six criteria, the first is usually considered to be the most significant (Bender, 1982, 9; Revsine, 1984). The financing currency, sales price responsiveness and the currency in which costs are incurred constitute other cardinal factors that need to be evaluated (Wojciechowski, 1982; Giannotti, 1982). FAS 52 mandates the following steps for carrying out the translation of a foreign entity's accounts into the parent company's reporting currency (Selling \& Sorter, 1983):

- identifying/designating the functional currency of the foreign entity on the premise of the economic environment in which it primarily operates;

- measuring all accounts of the financial statements in the functional currency;

- converting (translating) the values obtained in step (b) from the functional currency to the parent's reporting currency, in case the two currencies are different, using the current rate method;

- distinguishing the economic impact of changes in exchange rates on a net investment basis from the impact of such changes on individual assets and liabilities that are receivable or payable in currencies other than the functional currency.

It may be noted that FAS 52 has been substantively adapted into the Accounting Standard Code (ASC) promulgated by the United States Financial Accounting Standards Board (FASB) as ASC No. 830.30. This ASC of the FASB constitutes the complete source of the extant authoritative Generally Accepted Accounting Principles (GAAP) recognized by the FASB to be applied to nongovernmental entities. The ASC is effective for interim and annual periods ending after
September 15, 2009. It has been formulated through the comprehensive restructuring and reorganizing of the various pronouncements of the FASB from time to time and now, constitutes the sole authoritative diktat of the FASB on the US GAAP superseding all the erstwhile accounting standards. All accounting literature not explicitly included in the ASC has been declared to be non-authoritative by the FASB.

\section{WHAT IS „TRANSLATION ACCOUNTING"}

As mentioned above, the rapid advancement in communication technology has led to a collapse of trade barriers across the world. This, coupled with increased competition in domestic markets, has led firms to explore and set up business ventures outside their country of residence/incorporation. These ventures can take the form of foreign branches, joint ventures or subsidiaries or some similar organizational form in line with the laws of the foreign country. In such situations, the corporate laws or the accounting standards of most countries require that consolidated financial statements of the parent company with the foreign entity be made available to investors. The process of transforming various balance sheet and income statement items from the currency of the foreign entity to the reporting/home currency of the parent entity, e.g. for the purpose of consolidation, is called translation accounting (Bogicevic, 2013, 137).

When parent firms translate foreign currency accounts and amounts into their home currency equivalent amounts using the same exchange rate across all accounts, (i) the relative valuation of all assets and liabilities remains unchanged and (ii) there arises no surplus or deficit purely because of accounting translation since every account is multiplied by a constant factor. However, such an approach usually defeats the very objective of accounting translation as shall be alluded to in the sequel. When parent firms translate foreign currency amounts into their respective home currency equivalent amounts using partly the current exchange rate and partly the 
historical rate, changes in exchange rates do affect the parent's home currency valuation because some accounting items have home currency valuations different from those at the date of acquisition.

When the reported amount of accounting items of the subsidiaries varies as a result of a change in the exchange rate, accountants refer to the variance as a foreign exchange adjustment. This foreign exchange adjustment might conceivably be treated in one of the two ways:

- include the amount as a foreign exchange gain or loss in the computation of the net income for the period, which may then be closed out to retained earnings;

- include the amount as a foreign exchange adjustment in another comprehensive income, a separate component of the shareholders' equity account, bypassing the income statement and carrying it as a separate account in the balance sheet.

It is important to note that both these treatments result in the identical total shareholders' equity. They primarily differ with respect to the effects that the foreign exchange adjustment has on the net income and on particular shareholders' equity accounts.

\section{APPROACHES TO TRANSLATION ACCOUNTING}

In talking about the approaches to translation accounting, we are essentially involved in establishing a set of principles that would enable us to identify a set of exchange rates for the translation of various accounts appearing in the financial statements of the foreign entity. Although there are several approaches to translation that exist, those commonly adopted are the Current Value (Purchasing Power Parity) (PPP) Approach, the Current Rate Approach and the Temporal Approach. These are explained and analyzed below.

\section{Current Value (Purchasing Power Parity) (CV) Approach}

The „parity" relationships viz. Purchasing Power Parity (PPP), Interest Rate Parity (IRP) and Fisher's Open Condition (Levi, 1995) form the cornerstone of much of international finance. PPP (Cassell, 1923; Officer, 1983) mandates, in essence, that the same basket of goods in different countries should cost the same amount of money in the respective home currencies.

Under the CV (PPP) approach for translating assets and liabilities of foreign subsidiaries, all assets and liabilities, other than nonmonetary assets of the subsidiary, are translated at the current exchange rate i.e. the rate in vogue on the date of the preparation of the financial statements. However, nonmonetary assets that show value appreciation because of foreign inflation are first adjusted for foreign inflation and thereafter translated at the current rate. All income statement accounts are translated using exchange rates in vogue when the related revenue/expense flow is recognized.

The rationale for the CV (PPP) approach lies in the fact that it is misleading to apply the inflation adjusted exchange rate i.e. the current rate to assets whose values have not been adjusted upwards for the same inflation. Hence, the CV (PPP) method advocates that the fixed assets be initially adjusted for the subsidiary country's inflation and then be converted at the inflation adjusted exchange rate.

To analyze the implications of this method, particularly in the context of inflation rates of the parent's country and the subsidiary's country, we consider a US company (parent company) that sets up a wholly owned subsidiary in India (foreign company) towards the end of accounting period 20X0 (the base accounting period) by investing a sum of $E_{0}$ home currency (HC) units at an exchange rate of $S_{0} \mathrm{HC}$ units per FC. This exchange rate is assumed to remain unchanged till the end of the period 20X0 i.e. the beginning of the period 20X1, whereafter it moves during the period 20X1 in tandem with the principle of purchasing power parity. If $\pi_{h}$ and $\pi_{f}$ are the respective rates of inflation in the parent's home country and the subsidiary's 
home country, then PPP mandates that the year-end exchange rate for $20 \mathrm{X} 1$ would be:

$S_{1}=S_{0} \frac{1+\pi_{h}}{1+\pi_{f}}$

Let $M_{0}, F_{0}, I_{0}$ and $L_{0}$ be the value of monetary assets, fixed assets (valued at the historical cost in accordance with the convention), inventories (assumed nonmonetary) and liabilities (assumed monetary) at the end of the base period 20X0 in the subsidiary's currency (FC) and let $M_{p}, F_{p}, I_{l}$ and $L_{l}$ be the respective values at the end of the accounting period 20X1. To keep the issue of the analysis in focus and the figures tractable, we make the simplifying assumptions that (i) the depreciation in fixed assets is exactly offset by additional investments in the said assets so that $F_{I}=F_{0}$ and (ii) the level of physical inventories remains unchanged. The inventories at the end of the year 20X1 after being adjusted for the inflation of the subsidiary's country are $I_{1}=I_{0}\left(1+\pi_{f}\right)$ on the premise that the inflation influences all price levels uniformly.

At the end of the period 20X0, we then have:

$\frac{E_{0}}{S_{0}}=F_{0}-\left[L_{0}-\left(M_{0}+I_{0}\right)\right]$

The equation (2) identifies the proportion of the fixed assets that are deemed to be funded by the equity investment.

During the year 20X1, the subsidiary earns a profit of $N$ FC units, which is assumed to be retained in the business, i.e. no dividend is distributed for the year whence, the end of year 20X1 equation in FC units, corresponding to the equation (2) would read as:

$$
\begin{aligned}
& \frac{E_{0}}{S_{0}}+N=F_{1}-\left[L_{1}-\left(M_{1}+I_{1}\right)\right] \\
& =F_{0}-\left\{L_{1}-\left[M_{1}+I_{0}\left(1+\pi_{f}\right)\right]\right\}
\end{aligned}
$$

Let us, now, take up the translation of the subsidiary's accounts to the parent's HC units by the CV (PPP) method. $L_{1}$ and $\mathrm{M}_{1}$, both being valued at their current values on the balance sheet date are adjusted for foreign country inflation by default and need no further adjustment - they will be converted at the yearend exchange rate simply by multiplying their balance sheet values by $S_{I}$. In the above analysis, we have explicitly adjusted the inventory for the subsidiary country's inflation by valuing it on the balance sheet date at the then prevailing market price - no further adjustment is, thus, required and we shall simply multiply the balance sheet figure by $S_{I}$. In contrast to this, however, fixed assets have not been adjusted for the subsidiary country's inflation - they are being carried at historical cost in the accounts. It is, therefore, necessary to revalue them by a factor $\left(1+\pi_{f}\right)$ before converting at the current rate $S_{r}$. As mentioned earlier, the year's profit shall be converted at the appropriate weighted average rate, say $S_{a v}$. On making all these translations, we get the net translation adjustment as:

$\Delta_{C V}=\left\{\left[M_{1}+I_{1}+F_{1}\left(1+\pi_{f}\right)\right]-L_{1}\right\} S_{1}-E_{0}-N S_{a v}$

$=\left\{\left[M_{1}+\left(I_{0}+F_{0}\right)\left(1+\pi_{f}\right)\right]-L_{1}\right\} S_{1}-E_{0}-N S_{a v}$

$=\left(F_{0} \pi_{f}+\frac{E_{0}}{S_{0}}+N\right) S_{1}-E_{0}-N S_{a v}$

$=\left[\left(F_{0}-\frac{E_{0}}{S_{0}}\right) \pi_{f}+\frac{E_{0}}{S_{0}}\left(1+\pi_{f}\right)\right] S_{1}-E_{0}+N\left(S_{1}-S_{a v}\right)$

$=\frac{E_{0}}{S_{0}}\left[\left(1+\pi_{f}\right) S_{1}-S_{0}\right]+\left(F_{0}-\frac{E_{0}}{S_{0}}\right) \pi_{f} S_{1}+N\left(S_{1}-S_{a v}\right)$

$=E_{0} \pi_{h}+\left(F_{0}-\frac{E_{0}}{S_{0}}\right) \pi_{f} S_{1}+N\left(S_{1}-S_{a v}\right)$

The first term of the equation (4) represents the unrealized nominal inflationary holding gain resulting from the home country inflation (calculated on the parent's beginning net investment position): whereas the second term is the unrealized inflationary holding gain resulting from the foreign country's inflation calculated on the non-indexed local (foreign) debt financing of fixed assets. The third term is simply the exchange rate change effect on the year 20X1 earnings. The total reported gains in the books of the parent are $\Delta_{C V}+N S_{a v}$ and the real increase in the purchasing power of the parent due to the subsidiary's operations is $\Delta_{C V}+N S_{a v}-E_{0} \pi_{h}$. We present the above implications in a tabular form for ease of understanding (Table 1).

The translation of the aforesaid balance sheets to the parent's home currency units (HC) is carried out as follows (Table 2). 
Table 1 Foreign currency financial statements of subsidiary

\begin{tabular}{lcc}
\hline & $\mathbf{2 0 X \mathbf { X }}$ & $\mathbf{F C}$ \\
& & $\mathbf{2 0 X} \mathbf{1}$ \\
\cline { 2 - 3 } Net Income & & $N$ \\
\hline Balance Sheets & $M_{0}$ & $M_{l}$ \\
\hline Monetary assets & $I_{0}$ & $I_{I}=I_{0}\left(1+\pi_{f}\right)$ \\
Inventory & $F_{0}$ & $F_{0}$ \\
Fixed assets (Net) & $M_{0}+I_{0}+F_{0}$ & $M_{l}+I_{0}\left(1+\pi_{f}\right)+F_{0}$ \\
Total Assets & $L_{0}$ & $L_{l}$ \\
Less: Liabilities & $F_{0}-\left[L_{0}-\left(M_{0}+I_{0}\right)\right.$ & $F_{l}-\left[L_{l}-\left(M_{l}+I_{l}\right)\right.$ \\
Net worth & & \\
Represented by: & $E_{0} S_{0}^{-1}$ & $E_{0} S_{0}^{-1}$ \\
Common stock & $N i 1$ & $N$ \\
Retained earnings & & \\
\hline
\end{tabular}

Source: Author

Table 2 Translated home currency financial statements of subsidiary as on end of year 20X1

\begin{tabular}{|c|c|c|c|c|}
\hline & \multirow{2}{*}{$\begin{array}{c}\text { Inflation } \\
\text { Adjusted (FC) }\end{array}$} & \multicolumn{2}{|c|}{ Exchange } & \multirow[t]{2}{*}{$\mathrm{HC}$} \\
\hline & & Code & Rate & \\
\hline \multicolumn{5}{|c|}{ Income Statement (20X1) } \\
\hline Net Income & $N$ & $A$ & $S_{a v}$ & $N S_{a v}$ \\
\hline \multicolumn{5}{|c|}{ Balance Sheet as on $20 \mathrm{X} 1$} \\
\hline Monetary assets & $M_{1}$ & $C$ & $S_{1}$ & $M_{l} S_{l}$ \\
\hline Inventory & $I_{1}=I_{0}\left(1+\pi_{f}\right)$ & $C$ & $S_{1}$ & $I_{1} S_{1}$ \\
\hline Fixed assets (Net) & $F_{l}=F_{0}\left(1+\pi_{f}\right)$ & C & $S_{1}$ & $F_{l} S_{I}$ \\
\hline Total Assets & $M_{1}+I_{1}+F_{l}$ & & & {$\left[M_{l}+I_{1}+F_{1}\right] S_{l}$} \\
\hline Less: Liabilities & $L_{1}$ & C & $S_{1}$ & $L_{1} S_{1}$ \\
\hline Net worth & $F_{I}-\left[L_{I}-\left(M_{l}+I_{1}\right)\right]$ & & & $F_{l} S_{I}-\left[L_{l}-\left(M_{l}+I_{l}\right)\right] S_{l}$ \\
\hline \multicolumn{5}{|l|}{ Represented by: } \\
\hline Common stock & $E_{0} S_{0}^{-1}$ & $H$ & $S_{0}$ & $E_{0}$ \\
\hline Retained earnings & $N$ & & & $N S_{a v}$ \\
\hline $\begin{array}{l}\text { Revaluation } \\
\text { capital }\end{array}$ & $F_{0} \pi_{f}$ & & & $n / a$ \\
\hline $\begin{array}{l}\text { Economic gain } \\
\text { from exchange } \\
\text { rate change }\end{array}$ & & \multicolumn{2}{|c|}{ (forced) } & $\Delta_{C V}$ \\
\hline
\end{tabular}

Source: Author where:

$\Delta_{C V}=E_{0} \pi_{h}+\left(F_{0}-\frac{E_{0}}{S_{0}}\right) \pi_{f} S_{1}+N\left(S_{1}-S_{a v}\right)$.

It may be noted that in the above translation the fixed assets have been revalued upwards by the factor of $\pi_{f}$ to account for the foreign country's inflation. The economic gain due to the exchange rate change is analyzed in the following statement in line with the equation (4) (Table 3).

\section{Current Rate (CR) Approach}

As is apparent from the above, the process of translation involves two steps viz. (i) the valuation of the asset or liability or the recognition of the income or expense in accordance with some prescribed norms e.g. the GAAP of the subsidiary's home country to obtain the accounting value of the asset/liability or income/ expense in the subsidiary's home currency and (ii) the conversion of the value so obtained to the parent company's currency to facilitate consolidation.

While both the CV (PPP) and the CR approaches make identical prescriptions with regard to step (ii) - both mandating a conversion to be done at the exchange rate in vogue on the date of conversion, e.g. the balance sheet date in the case of assets and liabilities, and the date of the recognition of a transaction in the case of income/expense, they differ with respect to step (i). The former method requires a valuation of monetary as well as nonmonetary assets/liabilities (including fixed assets) to be done at the values that are adjusted for inflation in the subsidiary's country. The CR method, on the other hand, requires such a valuation to be done in conformity with the norms prescribed by the GAAP of the subsidiary's country. Thus, in this case, the valuation of fixed assets would, in most countries, be at their historical cost with no adjustment for the subsidiary country's inflation.

Proceeding to analyze the $\mathrm{CR}$ approach on the lines identical to the analysis of the CV (PPP) approach as above and using the same terminology, we obtain the translation adjustment, $\Delta_{C R}$ as: 
Table 3 Analysis of the economic gain arising from the translation of the accounts of the subsidiary at the end of year 20X1

(1) Unrealized Nominal Inflationary Holding Gain resulting from the home country's inflation (calculated on the parent's beginning net investment position):

\begin{tabular}{l|cc}
\hline & FC & HC \\
\hline $\begin{array}{l}\text { Subsidiary's equity at the beginning } \\
\text { of year 20X1 }\end{array}$ & $E_{0} S_{0}^{-1}$ & \\
$\begin{array}{l}\text { Unrealized gain due to the effect of } \\
\text { the domestic inflation }\left(\pi_{h}\right) \text { on the } \\
\text { exchange rate }\end{array}$ & & $E_{0} \pi_{h}$ \\
\hline
\end{tabular}

(2) Unrealized inflationary holding gain resulting from the foreign country's inflation (calculated on the non-indexed local (foreign) debt financing of the fixed assets):

\begin{tabular}{|c|c|}
\hline $\begin{array}{l}\text { Fixed assets at the beginning of } \\
\text { year } 20 \mathrm{X} 1\end{array}$ & $F_{0}$ \\
\hline $\begin{array}{l}\text { Less-Equity financing on the same } \\
\text { date }\end{array}$ & $E_{0} S_{0}^{-1}$ \\
\hline Net Debt Financing & $F_{0}-E_{0} S_{0}^{-1}$ \\
\hline $\begin{array}{l}\text { Unrealized inflationary gain due to } \\
\text { the effect of the foreign country's } \\
\text { inflation }\left(\pi_{f}\right) \text { on the exchange rate }\end{array}$ & $\left(F_{0}-E_{0} S_{0}^{-1}\right) \pi_{f} S_{l}$ \\
\hline
\end{tabular}

\section{(3) Exchange rate change effect on 20X1 earnings:}

\begin{tabular}{l|c}
$\begin{array}{l}\text { Reported earnings } \\
\text { Effect on income due to a difference } \\
\text { between the average rate and the } \\
\text { year-end rate }\end{array}$ & $N\left(S_{l}-S_{a v}\right)$ \\
$\begin{array}{l}\text { Total effect of the exchange rate } \\
\text { change (a net gain) }\end{array}$ & $\Delta_{C V}$ \\
\hline $\begin{array}{l}\text { (4) Subsidiary's net income } \\
\text { Reported HC the parent has } \\
\text { gained in 20X1 }\end{array}$ & $\Delta_{C V}+N S_{a v}$ \\
\hline $\begin{array}{l}\text { (5) Calculation of the parent's increase in purchasing power } \\
\text { in 20X1 }\end{array}$ \\
\hline $\begin{array}{l}\text { Reported (nominal) number of } \\
\text { HC ahead }\end{array}$ \\
$\begin{array}{l}\text { Less - A loss of purchasing } \\
\text { power on beginning investment } \\
\text { Real increase in purchasing } \\
\text { power }\end{array}$ \\
\hline
\end{tabular}

Source: Author

$$
\begin{aligned}
& \Delta_{C R}=\left\{\left[M_{1}+I_{1}+F_{1}\right]-L_{1}\right\} S_{1}-E_{0}-N S_{a v} \\
& =\left(\frac{E_{0}}{S_{0}}+N\right) S_{1}-E_{0}-N S_{a v} \\
& =\frac{E_{0}}{S_{0}}\left(S_{1}-S_{0}\right)+N\left(S_{1}-S_{a v}\right) \\
& =E_{0}\left(\frac{\pi_{h}-\pi_{f}}{1-\pi_{f}}\right)+N\left(S_{1}-S_{a v}\right) \\
& =E_{0} \pi_{h}-E_{0} \pi_{f}\left(\frac{1+\pi_{h}}{1+E_{0} \pi_{f}}\right)+N\left(S_{1}-S_{a v}\right) \\
& =E_{0} \pi_{h}-\frac{E_{0}}{S_{0}} \pi_{f} S_{1}+N\left(S_{1}-S_{a v}\right)
\end{aligned}
$$

The first term in the equation (5) represents an unrealized nominal inflationary holding gain on account of the home country's inflation. Incidentally, this figure coincides with the corresponding figure under the CV (PPP) method. The CR method, therefore, seems to report correctly the economic effect of the parent's home country inflation. The second term, that represents the inflation effect of the subsidiary's country, however, differs in the two cases by the $F_{0} \pi S_{1}$ factor - this is an upward valuation of the fixed assets of the subsidiary due to the subsidiary country's inflation in the CV (PPP) method. The CV (PPP) approach is consistent in the sense that it applies the inflation adjusted (downward adjusted) exchange rate to a figure that has likewise been adjusted upwards for the same inflation - the figure so obtained reflects the current value (in the parent's home currency terms) of the asset, i.e $F_{0}\left(1+\pi_{f}\right) S$. On the other hand, the CR method (for fixed assets) applies an inflation adjusted (downward) exchange rate to the historical cost of the asset (which is a figure unadjusted for inflation) viz. $F_{0} S_{l}$. The resulting figure is neither the parent's home currency equivalent required to acquire the fixed assets on the date that they were acquired which is $F_{0} S_{0}$ nor is it the current value of the said assets, which is $F_{0}\left(1+\pi_{f}\right) S_{l}$.

A phenomenon associated with the Current Rate approach is the "disappearing plant problem". An explanation for the same follows immediately from the aforesaid analysis. If the PPP holds, then $S_{1}=S_{0} \frac{1+\pi_{h}}{1+\pi_{f}}$. Now, if the parent country's inflation 
is less than the subsidiary country's inflation $S_{1}$ would gradually shift downwards with respect to $S_{0}$. In the CR method, there is no upward adjustment in fixed assets for the differential higher inflation of the subsidiary's country. As a fallout of these two factors, the product $F_{0} S_{l}$ (which is the reporting value of the fixed assets in the translated statements under the CR method) goes on decreasing without any depreciation charge. This constitutes the "disappearing plant problem".

\section{Temporal Approach}

The temporal approach preserves the "valuation" of an asset/liability, i.e. it synchronizes the "conversion" and the "valuation" steps - the exchange rate that is used for the translation of an asset or liability is determined by the mode of the valuation of the asset/liability. An asset/liability which is reported in the books of the subsidiary at the historical cost is converted (translated) at the historical exchange rate that was prevalent at the time of the acquisition/recognition of the asset/liability. Similarly, assets/liabilities that are reported at their respective market values on the date of the subsidiary's balance sheet are converted to the parent company's home currency at the exchange rates on the date of such reporting. The main issue of ambiguity that arises in the temporal method is with respect to inventory. If inventory is valued and reported at its historical cost, then the translation is also at the historical rates on the respective dates of the acquisition. However, if the reporting of inventory is done at the market value on the date of reporting, then the conversion shall also be at the exchange rate on the date of such reporting.

Income statement items are translated at the average exchange rates over the period, except for items associated with nonmonetary assets or liabilities such as the cost of goods sold (inventory) and depreciation (fixed assets), which are translated at their historical rates. Dividends paid are translated at the rates in effect on the payment date. Equity items are translated at their historical rates and include any imbalances.

We proceed to obtain an expression for the translation difference for both the scenarios viz. when inventory is carried at a market price and when it is carried at a historical cost. In addition to the notation above, we introduce St as the appropriately averaged exchange rate for translating the net income as per the temporal method. We have, in the case of market valued inventory:

$$
\begin{aligned}
& \Delta_{T E M P}=\left\{\left[M_{1}+I_{1}\right]-L_{1}\right\} S_{1}+F_{0} S_{0}-E_{0}-N S_{t} \\
& =\left(\frac{E_{0}}{S_{0}}+N-F_{0}\right) S_{1}+F_{0} S_{0}-E_{0}-N S_{t} \\
& =-\left(F_{0}-\frac{E_{0}}{S_{0}}\right)\left(S_{1}-S_{0}\right)+N\left(S_{1}-S_{t}\right) \\
& =\left(F_{0}-\frac{E_{0}}{S_{0}}\right) \pi_{f} S_{1}-\left(F_{0}-\frac{E_{0}}{S_{0}}\right) \pi_{h} S_{0}+N\left(S_{1}-S_{t}\right) \\
& =\Delta_{C V}-F_{0} \pi_{h} S_{0}+N\left(S_{a v}-S_{t}\right)
\end{aligned}
$$

If the inventory is valued at a historical cost, it will be converted at the historical exchange rate and the translation difference in such a situation will work out as follows:

$$
\begin{aligned}
& \Delta_{\text {TEMP }}^{*}=\left[M_{1}-L_{1}\right] S_{1}+\left(I_{0}+F_{0}\right) S_{0}-E_{0}-N S_{t} \\
& =\left(\frac{E_{0}}{S_{0}}+N-I_{0}-F_{0}\right) S_{1}+\left(I_{0}+F_{0}\right) S_{0}-E_{0}-N S_{t} \\
& =-\left(I_{0}+F_{0}-\frac{E_{0}}{S_{0}}\right)\left(S_{1}-S_{0}\right)+N\left(S_{1}-S_{t}\right) \\
& =\left(I_{0}+F_{0}-\frac{E_{0}}{S_{0}}\right) \pi_{f} S_{1}-\left(I_{0}+F_{0}-\frac{E_{0}}{S_{0}}\right) \pi_{h} S_{0}+N\left(S_{1}-S_{t}\right) \\
& =\Delta_{C V}-\left(I_{0}+F_{0}\right) \pi_{h} S_{0}+I_{0} \pi_{f} S_{1}+N\left(S_{a v}-S_{t}\right)
\end{aligned}
$$

The Table 4 summarizes the above results.

It is seen from the table and the preceding computations that the temporal method properly reports the effects of the subsidiary's home country inflation $\pi_{f}$ as $\left(F_{0}-E_{0} / S_{0}^{-1}\right) \pi S_{l}$. This is an unrealized inflationary holding gain and occurs because the same value of fixed assets occurs in the parent's HC under the temporal method irrespective of whether the subsidiary adjusts its fixed assets and exchange rate for the subsidiary's country's inflation or not, e.g. $F_{0} S_{0}=F_{0}\left(1+\pi_{f}\right) \frac{S_{0}}{\left(1+\pi_{f}\right)}=F_{a d j} S_{a d j}$ where $F_{a d j}$ and $S_{a d j}$ are respectively the fixed assets and the exchange rates adjusted for the subsidiary's home country inflation. 
Table 4 Comparison of reported effects of exchange rate changes

\begin{tabular}{|c|c|c|c|}
\hline & Temporal Method & $\begin{array}{l}\text { Current Value PPP } \\
\text { Method }\end{array}$ & Reporting Difference \\
\hline $\begin{array}{l}\text { Effect of the parent's home country inflation } \\
\text { Beginning investment }\left(E_{0} / S_{0}\right) \text { x upward } \\
\text { inflationary effect on exchange rate } \pi_{h} S_{0} \\
\text { Debt financing of fixed assets }\end{array}$ & $-\left(F_{0}-E_{0} / S_{0}^{-1}\right) \pi_{h} S_{0}$ & $E_{0} \pi_{h}$ & $\begin{array}{c}E_{0} \pi_{h} \\
\left(F_{0}-E_{0} / S_{0}^{-1}\right) \pi_{h} S_{0}\end{array}$ \\
\hline $\begin{array}{l}\left(F_{0}-E_{0} / S_{0}^{-1}\right) \pi_{h} S_{0} \text { upward inflationary effect on } \\
\text { exchange rate }\end{array}$ & & & $F_{0} \pi_{h} S_{0}$ \\
\hline $\begin{array}{l}\text { Debt financing of inventory: upward inflationary } \\
\text { effect }\end{array}$ & $-I_{0} \pi_{h} S_{0}$ & & $I_{0} \pi_{h} S_{0}$ \\
\hline \multicolumn{4}{|l|}{ Effect of Subsidiary country's inflation } \\
\hline $\begin{array}{l}\text { Debt financing of fixed assets of }\left(F_{0}-E_{0} / S_{0}^{-1}\right) \times \\
\text { downward inflationary effect on exchange rate } \\
\pi S_{1}\end{array}$ & $\left(F_{0}-E_{0} / S_{0}^{-1}\right) \pi S_{1}$ & $\left(F_{0}-E_{0} / S_{0}^{-1}\right) \pi S_{1}$ & $\mathrm{Nil}$ \\
\hline $\begin{array}{l}\text { Debt financing of inventory } I_{0} \times \text { downward } \\
\text { inflationary effect on exchange rate } \pi S_{1}\end{array}$ & $I_{0} \pi S_{l}$ & & $-I_{0} \pi S_{1}$ \\
\hline Effect of exchange rate change on net income & $N\left(S_{1}-S_{t}\right)$ & $N\left(S_{l}-S_{a v}\right)$ & $N\left(S_{t}-S_{a v}\right)$ \\
\hline Reported effect of exchange rate change & $\Delta_{T E M P}^{*}$ & $\Delta_{C V}$ & $\Delta_{C V}-\Delta_{T E M P}^{*}$ \\
\hline $\begin{array}{l}\text { Explanation of the Reporting Difference } \\
\Delta_{C V}-\Delta_{T E M P}^{*}\end{array}$ & & & \\
\hline Suppressed valuation of fixed assets & & & $F_{0} \pi_{h} S_{0}$ \\
\hline Overvaluation of inventory & & & $I_{0} \pi_{h} S_{0}-I_{0} \pi_{f} S_{l}$ \\
\hline $\begin{array}{l}\text { Difference due to use of historical rates for } \\
\text { converting depreciation and cost of sales }\end{array}$ & & & $N\left(S_{t}-S_{a v}\right)$ \\
\hline
\end{tabular}

Source: Author

However, the temporal method does not properly report the $E_{0} \pi_{h}$ economic effect of the upward inflationary effect of the exchange rate $S_{0} \pi_{h}$ that is caused by the parent's home country inflation $\pi_{h}$. This is an unrealized nominal inflationary holding gain. The source of this anomaly can be traced to the use of the historical rate $S_{0}$ to translate the fixed assets implying that the upward factor of $S_{0} \pi_{h}$ was not considered in determining the fixed asset amount in the parent's HC. As seen above, the valuation of fixed assets under the temporal method is $F_{0} S_{0}=F_{0}\left(1+\pi_{f}\right) \frac{S_{0}}{\left(1+\pi_{f}\right)}=F_{a d j} S_{a d j}$. This needs to be contrasted with the CV (PPP) valuation of fixed assets, which is $F_{1} S_{1}=F_{0}\left(1+\pi_{f}\right) \frac{S_{0}\left(1+\pi_{h}\right)}{\left(1+\pi_{f}\right)}$. It is clearly seen that the temporal method suppresses the fixed asset valuation by a factor $S_{0} \pi_{h}$ i.e. an absolute valuation of $F_{0} S_{0} \pi_{h}$ compared to the CV (PPP) method. In fact, the temporal method would also fail to report correctly the economic effect of noninflationary factors, if present, because such factors are dealt with in the same manner as the parent's home country inflation.

\section{FAS 52 - SOME ISSUES}

There are two main issues that need determination in the context of the translation of accounts from one currency to another. They are (i) which translation method is to be used and (ii) in what manner the 
translation gains and losses are to be accounted for. We analyze the provisions of FAS 52 in this backdrop.

The first pronouncement of the Financial Accounting Standards Board (FASB) of the United States in the context of translation accounting came in 1975 through FAS 8. Prior to the announcement of FAS 8, US companies could select any of the acceptable translation methods for the conversion of accounts from one currency to the other and could also report translation gains and losses either in the income statement or directly to stockholders' equity. In a study initiated by the FASB, it was found that in the pre-FAS 8 era, most firms used either the current-noncurrent method or the monetary-nonmonetary approach with an immediate disposition of translation gains and losses to the income statement (Evans, Folks \& Jilling, 1978). However, FAS 8 changed the situation radically and mandated that only the temporal method be used for translation and that the translation adjustment be necessarily routed through the income statement. The temporal method was believed to have the advantage of preserving the valuation attribute of an asset/ liability. Although FAS 8 finally required that all translation gains and losses be closed to the income statement, the possibility of deferring such translation gains and losses was given explicit consideration by the FASB in cases where such gains/ losses were likely to reverse in future. However, it was felt that objectivity in measurement would not be practicable in identifying and/or quantifying such reversible gains and losses.

However, it was soon realized that the adoption of FAS 8 by companies and the consequential transfer of translation gains and losses to the income statement resulted in an enhanced volatility of earnings due to the fluctuations of exchange rates (Shank, Dillard \& Murdock, 1979). This was unwarranted and opposed by the corporate fraternity. Besides, the mechanized and injudicious adoption of the temporal method resulted in instances where translation gains and losses were inconsistent with the economic reality. Thus, FAS 8 was short lived and in 1981, FASB responded with the pronouncement of FAS 52.

FAS 52 brought into the rulebook the concept of the „functional currency" for the first time. Under FAS 52, translation is achieved as a two stage procedure viz. (i) the identification of the "functional currency" of the subsidiary and (ii) the conversion of the accounts of the subsidiary to the parent company's reporting currency and the disposition of the gains and losses of translation in conformity with the functional currency identified under stage (i). For this purpose, FAS 52 defines the "functional currency" of the subsidiary as "the currency of the primary economic environment in which the subsidiary operates". In the event of the subsidiary's functional currency being a foreign currency (other than the US Dollar), FAS 52 mandates (i) the use of the current rate method for the conversion of the subsidiary's accounts to the parent's HC and (ii) the disposition of the translation gains and losses by direct transfer to the stockholders' equity. However, if the subsidiary's functional currency is identified as the US Dollar, then such conversion is to be done by the temporal method and the gains and losses of translation are to be closed to income.

In cases where the functional currency of the subsidiary is a third currency other than the local currency of the subsidiary and the US Dollar, the subsidiary's statements must first be translated from the local currency into the functional currency and then translated into US Dollars. On the basis of the above, the following rules for the translation method and recognition of translation gains or losses can be identified:

- when translating into the functional currency, the temporal method is to be used and gains and losses on translation are to be closed to the income statement;

- when translating from the functional currency, the current rate method is to be adopted and translation gains/losses are to be carried as part of stockholders' equity.

It is important to understand the implications of FAS 52 at this point. The translation of the balance sheet items at the current rate implies that these items are exposed to an exchange rate risk. It follows from the prescription of FAS 52 that:

- if the foreign subsidiary operates in an economic environment that results in the identification of 
the foreign currency as its functional currency, then the entire net investment in the subsidiary of the parent is exposed to exchange rate risk; and

- because translation gains and losses are directly carried to the stockholders' equity, such gains or losses may be deemed to be unrealized until the subsidiary is liquidated;

- if the foreign subsidiary operates in an economic environment that results in the identification of the US Dollar as its functional currency, then only the monetary assets and liabilities (that are translated at the current rate under the temporal method) of the subsidiary are exposed to an exchange rate risk; and

- in such a case, because translation gains and losses are closed to the income statement of the current year, such a gain or loss may be deemed to be actually realized in the current year.

This aspect of FAS 52 warrants further investigation. As mentioned above, the use of the current rate method for the conversion of the subsidiary's accounts to the parent's HC implies that all assets and liabilities (whether monetary or nonmonetary) are subject to an exchange rate risk. But is it really so? Let us, first, examine the case where the Purchasing Power Parity (PPP) holds between the parent's and the subsidiary's home countries. Using the notation aforesaid, we consider a nonmonetary asset $X$ of the subsidiary with the respective values $X_{0}$ and $X_{1}$ at time $t=0$ and $t=1$ in the subsidiary's HC. Further, the PPP exchange rate at $t=l$ is $S_{1}=S_{0} \frac{1+\pi_{h}}{1+\pi_{f}}$ whence the valuation of this asset (ignoring the effect of the subsidiary's country's inflation on the value of the asset) in the parent's HC as per the CR method would be $X_{0} S_{I}$. This would result in an economic gain/loss due to the exchange rate change of $\quad X_{1} S_{1}-X_{0} S_{0}=X_{0}\left(S_{1}-S_{0}\right)=X_{0} S_{0} \frac{\pi_{h}-\pi_{f}}{1+\pi_{f}}$. The parent's HC valuation of the asset would remain unchanged if $X_{1} S_{1}-X_{0} S_{0}=0$ or $\frac{X_{1}}{X_{0}}=\frac{S_{0}}{S_{1}}$ i.e. the percentage increase in the subsidiary's valuation of the asset at $t=1$ is equivalent to the percentage fall in the exchange rate at the same point in time.
Let us look at the impact of the PPP on the above analysis now. Assuming that inflation is uniform across all the sectors, we have $X_{1}=X_{0}\left(1+\pi_{f}\right)$. Further, the PPP exchange rate at $t=1$ is given by $S_{1}=S_{0} \frac{1+\pi_{h}}{1+\pi_{f}}$ whence the translated value of the asset in the $\mathrm{HC}$ of the parent (if the valuation of the asset is adjusted for the inflation of the subsidiary's home country) works out to $X_{1} S_{1}=X_{0}\left(1+\pi_{f}\right) S_{0} \frac{1+\pi_{h}}{1+\pi_{f}}=X_{0} S_{0}\left(1+\pi_{h}\right)$.

In real terms, in the parent's reporting currency, (i.e. the constant Dollar value) this is $X_{0} S_{0}$. Thus, if the PPP holds and the asset value is adjusted for the subsidiary's home country's inflation, then the asset value in real terms in the parent's reporting currency remains unchanged. Consequently, in such a scenario, the nonmonetary assets of the subsidiary are not exposed to an exchange rate risk. It may be noted, in passing, that the use of the temporal method results in an unchanged valuation for nonmonetary assets indicating no risk exposure for such assets and is, therefore, compatible with the holding of the PPP. We can thus say that, in an environment where the PPP is believed to hold, the nonmonetary assets of the foreign subsidiary would not be exposed to an exchange rate risk, there would be no change in the valuation and the temporal method achieves this objective.

Unfortunately, the situation radically changes if the subsidiary operates in an environment in which PPP holds only partly or does not hold altogether. The translation of nonmonetary assets does not result in unchanged valuations in real terms. These assets become exposed to an exchange rate risk. Gains or losses on translation are no longer zero and are dependent on the extent to which a change in exchange rates diverges from the PPP mandated rates. Since the temporal method is not influenced by the PPP, it continues to result in zero translation gains/ losses. This method, therefore, loses its efficacy as an appropriate translation method if the PPP principle is violated. Let us assume that $S_{1}^{*}$ is the actual exchange rate and $S_{1}=S_{0} \frac{1+\pi_{h}}{1+\pi_{f}}$ is the rate predicted by the PPP. The deviation of the exchange rate from the PPP is, therefore, $S_{1}^{*}-S_{1}$ and it yields an economic gain of $X_{0}\left(S_{1}^{*}-S_{1}\right)$ on a nonmonetary asset. If the CV (PPP) 
method be adopted for conversion, the asset would be recorded at $X_{0} S_{0}+X_{0}\left(S_{1}^{*}-S_{1}\right)$. The economic gain of $X_{0}\left(S_{1}^{*}-S_{1}\right)$ would be closed to the income statement for the period. On the other hand, the use of the current rate method would record a loss of $X_{0} S_{0}-X_{0} S_{1}^{*}$ while the use of the temporal method would result in no gain and no loss.

In view of the aforesaid, it may well be concluded that the criterion of choosing an appropriate method for the translation of nonmonetary assets should relate to the extent to which the PPP holds between the parent's country and the subsidiary's country. The mere identification of a functional currency on the basis of the economic environment and relating the translation method thereto leads to inconsistent results for nonmonetary assets as analyzed above. Insofar as monetary assets and liabilities are concerned, there seems no point in disputing as these are valued at the current market price and hence their values get adjusted for inflation by default. They get converted to the parent's reporting currency at the current rate thereby ensuring consistency in results.

Linked to the above is another cardinal issue relating to the implementation of FAS 52 viz. whether translation gains and losses should be closed to the income statement of the relevant year or that they should be taken directly to stockholders' equity. The guiding principle here should be that if translation gains and losses are likely to be of a permanent nature, they need to be written off to the income statement of the current year, while if such gains and losses are temporary, i.e. there is a significant probability of their being reversed in the future, then they need to be carried to stockholders' equity. This prescription would also be consistent with the treatment of gains and losses on noncurrent investments in marketable securities (FAS 12). In fact, it needs to be so because investments in a foreign subsidiary may be construed as a special case of an investment in noncurrent marketable securities. Therefore, rather than relating the method of the disposition of translation gains and losses to the method of conversion viz. the current rate method or the temporal method and consequently to the identification of the functional currency, the benchmark for such disposition should be the temporal nature of translation gains and losses - gains and losses of a permanent character need to be closed to the relevant income statement while those that seem reversible in the future may be carried forward as such as part of stockholders' equity.

In this context, a further refinement may be contemplated. For monetary items, deviations from the PPP are irrelevant so that a possibility of reversals in translation gains and losses may be linked directly to exchange rates. However, for nonmonetary assets, deviations from the PPP must become the determining factor, i.e. gains and losses should be recognized as income, if the PPP is violated and they need to be carried to stockholders' equity if the PPP holds. This is because exchange rate changes also contain a component traceable to relative inflation - this would be reflected in the nominal asset values to the extent the PPP holds. Hence, it becomes necessary to isolate the component of exchange rates that represents deviations from the PPP and it is the temporal character of these deviations that needs to be examined for ascertaining the mode of the disposition of the related translation gains and losses.

\section{FAS 52 VERSUS IAS 21}

The provisions of FAS 52 and the corresponding IFRS standard (IAS 21) are substantially similar. Nevertheless, it is instructive to identify the points of resemblance and those of variance between the two standards.

Both of these standards require a foreign entity to measure its assets, liabilities, revenues and expenses in its functional currency. The functional currency is defined in both standards as the currency of the primary economic environment in which the entity operates. However, the set of indicators that need to be considered in arriving at an identification of the functional currency differs among the two standards. While FAS 52 requires that equal emphasis be given to each of the prescribed criteria, IAS 21 prescribes the primary set of criteria that need to be considered first in deciding upon the functional currency. If the evaluation of the primary criteria leads to inconclusive 
results, recourse may be had to the secondary set of criteria.

Under IAS 21, the primary economic environment in which a foreign entity operates is the one in which it generates and expends cash. Cash flows of primary importance are those related to the purchase and sale of goods and services, e.g:

- the currency that primarily influences sales prices for goods and services;

- the currency of the country whose competitive forces and regulations primarily influence the sales prices;

- the currency that primarily influences the prices of inputs viz. labor, material, and other costs of providing goods and services.

The secondary set of indicators to be considered under IAS 21, if the above three factors are inconclusive, are as follows:

- the currency in which the foreign entity generates funds from financing;

- the currency in which the foreign entity retains cash flows from operating activities;

- the proportion of the activities of the foreign entity with the reporting entity;

- the extent to which the cash flows from the activities of the foreign entity remain with the foreign entity or are readily available for remittance to the reporting entity;

- the extent to which the cash flows of the foreign entity are sufficient to service debt obligations without funds from the reporting entity;

- whether the activities of the foreign entity are an extension of the reporting entity or are carried out with a significant degree of autonomy.

Thus, the two important differences between FAS 52 and IAS 21 with respect to identifying the functional currency are:

- FAS 52 uses a broad spectrum of operating and financing criteria, whereas IAS 21 places a heavier weight on the currency in which a foreign entity makes purchases and sales of goods and services;

- FAS 52 uses a distinction between an autonomous foreign unit and a unit operating as an extension of the parent as a primary scheme for identifying the functional currency, whereas IAS 21 treats this distinction as the only one additional factor to consider.

Both standards allow a foreign entity to present its financial statements in a currency other than its functional currency (reporting currency). IAS 21 also allows for the case of an entity having multiple reporting currencies.

Transactions that are not denominated in a foreign entity's functional currency are deemed to be foreign currency transactions. Exchange differences arising from foreign currency transactions are generally closed to the income statement under the provisions of both standards. If a foreign entity has foreign operations, both standards prescribe a similar scheme of translation for the purpose of consolidation viz. assets and liabilities to be translated at the closing rate, revenues and expenses at actual rates or appropriate averages and equity components at the historic rates.

In FAS 52, the financial statements of a foreign operation in a highly inflationary economy are required to be re-measured as if the parent's reporting currency were its functional currency with translation gains and losses recognized in income. However, IAS 21 prescribes that if the functional currency of a foreign operation is hyperinflationary, then current purchasing power adjustments be made to its financial statements prior to translation. Financial statements are thereafter translated at the closing rate at the end of the current period.

Both accounting standards prescribe that when an investment in a foreign operation is disposed of, the cumulative exchange differences recognized previously in equity/other comprehensive income should be recognized to income. Furthermore, when financial statements are translated into a presentation currency other than the entity's functional currency, the entity should use the same method as for translating financial statements of a foreign operation. 


\section{CONCLUSION}

On the basis of the analysis and the deductive reasoning of the relevant theoretical models presented in the aforesaid sections, the following hypotheses stand vindicated/established:

- The Current Value (Purchasing Power Parity) Method of translation correctly reports the effects of the parent country's inflation and the foreign subsidiary country's inflation;

- The Current Rate Method of translation correctly reports the effects of the parent country's inflation but does not correctly report the foreign subsidiary country's inflation;

- The Temporal Method of translation does not correctly report the effects of the parent country's inflation but correctly reports the foreign subsidiary country's inflation;

- The procedure prescribed under the provisions of FAS 52 for the translation of a foreign subsidiary's accounts correctly reports the effects of the pricelevel changes in the two countries if and only if the principle of the Purchasing Power Parity holds between the two countries.

The aforesaid analysis does have its limitations. At the very outset, the identification of the functional currency under FAS 52 is substantially subjective with an ample scope for manipulation or even, unintentional judgment error in the application of the prescribed tests. The survey results have in fact vindicated the existence of such instances (Griffin \& Castanias, 1987; Heines, 1986; Stanley \& Stanley, 1978).

Furthermore, while the theoretical underpinnings of relating the method of translation and the disposition of translation gains and losses to the PPP seem to be sound, the framework is unquestionably beset with several practical impediments. At the very outset, it needs to be empirically established that the PPP constitutes the cardinal force driving exchange rates and that other factors like a balance of trade etc. constitute no more influence than the proverbial "noise" in stochastic systems. Considerable research work has been done in this context (Aliber \& Stickney,
1975; Hall, 1983; Wyman, 1976; Ziebart, 1985), following different methodologies with inconsistent outcomes and inferences.

The proposed algorithm attempts to identify the translation and disposition methods on the premise of ",whether the PPP holds". Accordingly, the criterion to infer the "holding of the PPP" needs to be laid out by accounting regulators, i.e. a "materiality threshold" needs to be set, such that if the deviations between the PPP mandated exchange rates and the actual exchange rates fall below this "threshold", the PPP may be deemed to hold and not otherwise . Since this would involve statistical hypotheses testing, appropriate „significance levels' also need to be defined together with the time periods over which observations are to be analyzed. In spite of the existence of these operational issues, it cannot be denied that the framework outlined above constitutes a more rational and logical premise for accounting for translation than the provisions of the extant FAS 52 and the related functional currency concept.

\section{REFERENCES}

Aliber, R. Z., \& Stickney, C. P. (1975). Accounting measures of foreign exchange exposure: The long and short of it. The Accounting Review, 50(1), 44-57.

Bender, D. E. (1982). Foreign Currency Translation - FAS 52 Part 1. The CPA Journal, 52.

Bogicevic, J. (2013). Accounting implications of foreign currency transaction translation and hedging. Economic Horizons, 15(2), 133-148. doi: 10.5937/ekonhor1302133B.

Cassell, G. (1923). Money and Foreign Exchange after 1914. New York, United States: McMillan.

Evans, T., Folks, W., \& Jilling, M. (1978). The impact of statement of financial accounting standards no. 8 on foreign exchange risk management practices of American multinationals: an economic impact study. New York, United States: Financial Accounting Standards Board.

Evans, T. G., \& Doupnik, T. S. (1986). Determining the Functional Currency under Statement 52. Stanford CT, United States: Financial Accounting Standards Board.

Giannotti, J. B. (1982). FAS 52 Gives Treasurers the Scope FAS 8 Denied Them. Euromoney, April, 146. 
Griffin, P. A., \& Castanias R. P. (1987). Accounting for the Translation of Foreign Currencies: The Effects on Equity Analysts. Stanford CT, United States: Financial Accounting Standards Board.

Hall, T. (1983). Inflation and rates of exchange: Support for SFAS 52. Journal of Accounting, Auditing \& Finance. Summer, 299.

Heines, J. (1986). What Do Open Marriages and the Accounting Rules for Changes in Foreign Exchange Rates Have in Common? Plenty of Opportunity to Fool Around. Forbes, 137, June 1, 139.

Hosseini, A., \& Rezaee, Z. (1988). Choice of functional currency under SFAS No. 52. Journal of Applied Business Research, 4(4), 21-27.

Levi, M. (1995). International Finance. New York, United States: McGrawHill.

Officer, L. (1983). Purchasing Power Parity and Exchange Rates: Theory, Evidence, and Relevance. London, United Kingdom: JAI Press.

Revsine, L. (1984). The rationale underlying the functional currency choice. The Accounting Review, 59(3), 505-514.

Selling, T. I., \& Sorter, G. H. (1983). FASB Statement No. 52 and its implications for financial statement analysis. Financial Analysts Journal, 39(3), 64-69.

Shank, J., Dillard, J., \& Murdock, R. (1979). Assessing the Economic Impact of FAS 8. New York, United States: Financial Executive Research Foundation.

Stanley, M. T., \& Stanley, B. B. (1978). Responses by United States Financial Managers to Financial Accounting Standard No. 8. Journal of International Business Studies, 9(2), 89-99 doi:10.1057/palgrave.jibs. 8490665

Wojciechowski, S. R. (1982). Du Pont evaluates FAS 52. Management Accounting, 64, 30-35.

Wyman, H. (1976). Analysis of gains or losses from foreign monetary items: An application of purchasing power parity concepts. The Accounting Review, 51(3), 545-558.

Ziebart, D. A. (1985). Exchange rates and purchasing power parity: Evidence regarding the failure of SFAS No. 52 to consider exchange risk in hyper-inflationary countries. The International Journal of Accounting, Fall, 39-51.

\section{Received on $10^{\text {th }}$ June 2014, after revision, accepted for publication on $19^{\text {th }}$ August 2014.}

Jatinder Pal Singh, PhD, is a Professor at the Indian Institute of Technology Roorkee and a professional member of the Institute of Chartered Accountants of India, Institute of Cost Accountants of India, Institute of Company Secretaries of India and Institution of Engineers (India). His research interests are in econophysics, mathematical finance, financial risk management, international finance and corporate governance. 


\title{
O EFIKASNOSTI METODA PREVOĐENJA VALUTA I PRISTUPU FUNKCIONALNE VALUTE U IZVEŠTAVANJU O PROMENAMA NIVOA CENA
}

\author{
Jatinder P. Singh \\ Departman za studije menadžmenta, Institut za tehnologiju, Roorkee, Uttarakhand, India
}

\begin{abstract}
Ovaj rad se bavi evaluacijom računovodstva prevođenja valuta kroz logičku i deduktivnu analizu koncepata. Istražuje se veza između inflacije u konstitutivnim državama i metoda prevođenja valuta. Utvrđeno je da samo Metod tekuće vrednosti pruža tačne podatke o efektima inflacije u obema državama. Metod tekućeg kursa ne pruža tačne podatke o efektu inflacije $u$ državi supsidijaru, a temporalni metod ne daje tačne podatke o efektu inflacije u matičnoj državi. U radu se ispituje efikasnost FAS 52 (SAD) i koncepta funkcionalne valute. Po FAS 52, funkcionalna valuta određuje metod koji će biti usvojen za prevođenje valuta i račune supsidijara koji podležu kursnom riziku. Međutim, postoji mišljenje da se kursni rizik odnosi na narušavanje pariteta kupovne moći. Stepen narušavanja pariteta kupovne moći trebalo bi, dakle, da oblikuje premisu na kojoj bi trebalo opredeliti funkcionalnu valutu i metod prevođenja.
\end{abstract}

Ključne reči: izloženost strane valute, izloženost prevođenja, metod tekućeg kursa, temporalni metod, paritet kupovne moći, FAS 52, funkcionalna valuta

JEL Classification: M41 